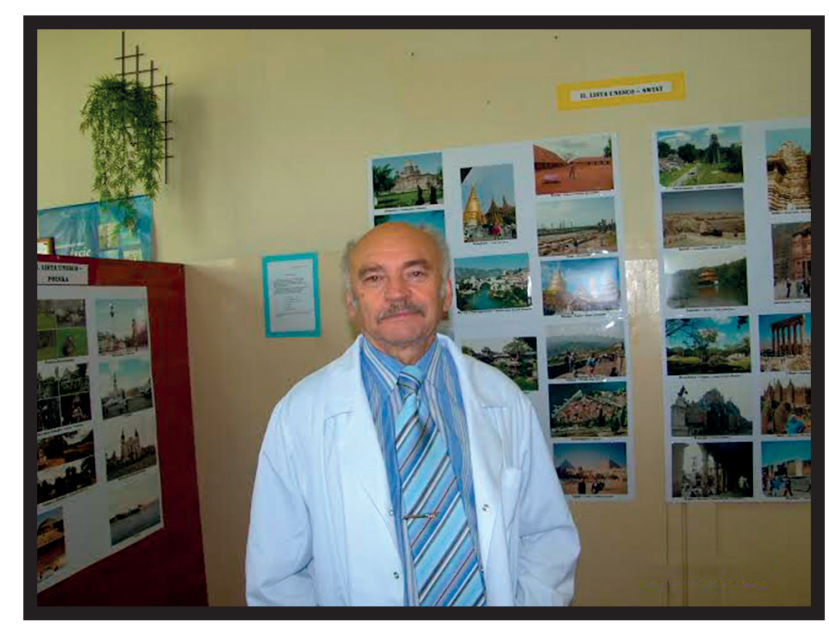

\title{
Doktor n. med. Kazimierz Kalbarczyk
}

\section{$7.06 .1935-20.11 .2013$}

Przegl Dermatol 2014, 101, 229-231

Odszedł dr n. med. Kazimierz Kalbarczyk - legenda Szpitala Dermatologicznego im. św. Łazarza w Warszawie, Mistrz i Nauczyciel wielu pokoleń lekarzy, zapalony diagnosta i dydaktyk łączący wiedzę kliniczną ze znajomością histopatologii skóry. Ponad pół wieku, do ostatniego dnia życia, pracował jako lekarz dermatolog. 20 listopada 2013 roku nie stawił się do pracy w Poradni Dermatologicznej na Lesznie. Czekaliśmy...

Doktor Kazimierz Kalbarczyk urodził się w czerwcu 1935 roku w Kochowie koło Maciejowic. Z rodzinnych stron wyemigrował po ukończeniu szkoły powszechnej i zamieszkał u stryja Aleksandra w Pruszkowie, gdzie w 1953 roku zdał maturę w liceum ogólnokształcącym. W 1958 roku ukończył Wydział Lekarski Akademii Medycznej w Białymstoku i w Szpitalu Powiatowym w Ełku rozpoczął 2-letni staż podyplomowy. W 1960 roku został kierownikiem Przychodni Miejskiej w Goniądzu w województwie białostockim. W 1964 roku uzyskał specjalizację I stopnia z dermatologii i wenerologii w Klinice Dermatologicznej w Białymstoku, a w 1965 roku zaczął pracę w Otwocku jako kierownik Powiatowej Poradni Skórno-Wenerologicznej i zastępca dr hab. med. Wacława Gutowskiego, ordynatora oddziału dermatologicznego w szpitalu miejskim. W 1969 roku uzyskał specjalizację II stopnia z dermatologii i wenerologii. W 1974 roku obronił pracę doktorską w Akademii Medycznej w Warszawie, co było ogromnym wyzwaniem dla lekarza pracującego poza ośrodkiem klinicznym w podwarszawskiej miejscowości. Promotorem pracy pt. „Znaczenie kliniczne badań immunopatolo- gicznych w liszaju płaskim" był prof. Tadeusz Chorzelski.

W 1976 roku dr Kalbarczyk objął stanowisko ordynatora oddziału dermatologicznego w Otwocku. W okresie otwockim opublikował jako autor lub współautor kilkanaście prac naukowych obejmujących zagadnienia kliniczne i metody terapii m.in. toxic epidermal necrolysis po antybiotykach, carcinoma spinocellulare dyskeratoticum segregans $\mathrm{z}$ licznymi przerzutami do skóry, leczenie hydrazydem liszaja płaskiego, vasculitis nodosa o nietypowym obrazie histopatologicznym.

Po przeniesieniu w 1981 roku oddziału otwockiego dr Kalbarczyk związał się ze Stołecznym Szpitalem Dermatologicznym św. Łazarza w Warszawie, gdzie przez ponad 20 lat był ordynatorem oddziału IV. W latach 1990-1998 dodatkowo pełnił funkcję dyrektora ds. lecznictwa. W 1994 roku uzyskał II stopień specjalizacji z organizacji ochrony zdrowia. Po likwidacji oddziału dermatologicznego, którym kierował do 31 sierpnia 2002 roku, został konsultantem ds. dermatologii i histopatologii w Szpitalu Dermatologicznym św. Łazarza i Przyszpitalnej Przychodni Dermatologicznej.

Doktor Kazimierz Kalbarczyk był zapalonym dydaktykiem. Pod jego kierunkiem uzyskało specjalizację 40 lekarzy, w tym 20 drugi stopień. Jego pasją była histopatologia skóry - prowadził szkolenia dla lekarzy od ponad 20 lat. Nigdy nie robił tajemnicy ze swojej wiedzy, $\mathrm{z}$ wielkim zapałem uczył młodych lekarzy. Poza pracą kliniczną i dydaktyczną publikował artykuły z zakresu dermatologii, zawsze z do- 
skonałą dokumentacją kliniczną i histopatologiczną - sam robił zdjęcia i opisy histopatologiczne. Łącznie w okresie otwockim i warszawskim opublikował w piśmiennictwie krajowym i zagranicznym ponad 40 prac. Poruszane zagadnienia to sarkoidoza skóry i płuc, gruźlica skóry, zespół Sweeta, zespół Sweeta postać paraneoplastyczna, świerzb guzkowy, obraz kliniczny i histopatologiczny niepożądanych odczynów skórno-węzłowych po szczepieniach BCG, dyskeratoza akantolityczna i inne.

Od wielu lat, zgodnie z tradycją, razem z zespołem lekarzy ze Szpitala Dermatologicznego św. Łazarza i Przyszpitalnej Przychodni Dermatologicznej przygotowywał czerwcowe posiedzenia naukowe Oddziału Warszawskiego Polskiego Towarzystwa Dermatologicznego, prezentował także przypadki w Klinice Dermatologicznej. Jako autor lub współautor przedstawił ponad 500 przypadków. W latach 1995-2000 i 2000-2002 był wiceprezesem Oddziału Warszawskiego Polskiego Towarzystwa Dermatologicznego oraz dwukrotnie otrzymał nagrodę PTD za prace naukową: w 1993 roku indywidualnie, a w 2000 roku wspólnie z Przyszpitalną Przychodnią Dermatologiczną, z którą ściśle współpracował i konsultował wiele przypadków.

Doktor Kazimierz Kalbarczyk zawsze był oddany chorym. Od wielu lat prowadził gabinet dermatologiczny w Otwocku i w Warszawie, gdzie pacjenci z Warszawy i województwa mogli zawsze liczyć na Jego pomoc. Wśród chorych krążyło nawet powiedzenie, że jeśli ci doktor Kalbarczyk nie pomoże, to już nikt ci nie pomoże.

Szczególnie lubił tzw. trudne, nietypowe, przypadki - dotąd szukał w piśmiennictwie, konsultował w Klinice Dermatologicznej, aż ustalił rozpoznanie i wdrożył leczenie. Przypadki te prezentował na posiedzeniach Oddziału Warszawskiego i zjazdach krajowych PTD: elastosis perforans serpiginosa po leczeniu Cuprenilem choroby Wilsona, keratosis palmo-

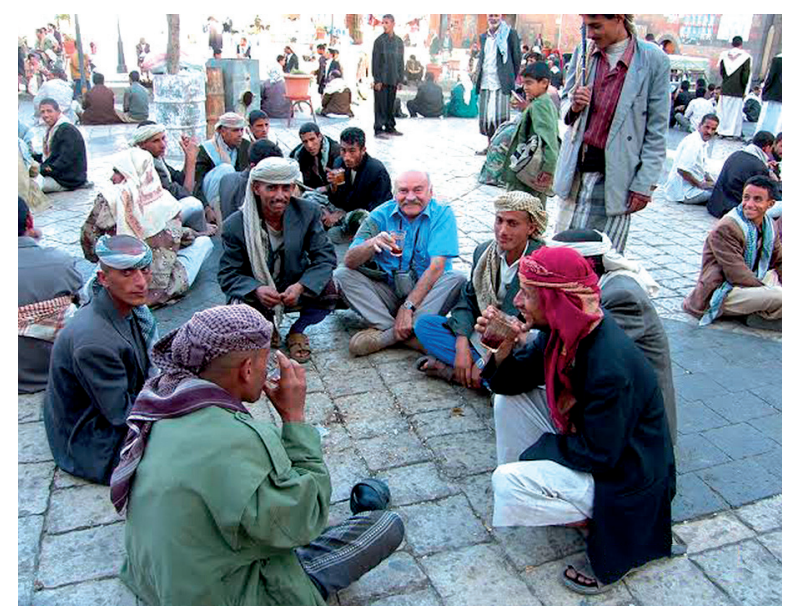

Rycina I. Popołudniowa herbata na Półwyspie Arabskim plantaris mutilans - zespół Vohvinkela, choroba Degosa, keratoacanthoma multiplex varietas Grzybowski, reticulohistiocytoma, parakeratosis variegata, naczyniaki gumiaste, przerzuty raka sutka do skóry, zespół Sezary'ego, tricholemmoma malignum, sarcoma Kaposi multiplex i inne, a w sesjach plakatowych np. obraz kliniczny i histopatologiczny zmian na żołędzi, wybrane nowotwory skóry. Przez 20 lat (do 1998 roku) był konsultantem dla województwa siedleckiego. W wielu poradniach tego województwa (Siedlce, Garwolin, Węgrów, Łuków, Mińsk Mazowiecki) pracują dermatolodzy wyszkoleni przez dr. Kalbarczyka.

Po likwidacji Szpitala Dermatologicznego św. Łazarza w październiku 2007 roku został konsultantem ds. dermatologii i histopatologii w Międzyleskim Szpitalu Specjalistycznym i w nowo utworzonej Poradni Dermatologicznej na Lesznie w Warszawie. Mimo przejścia na emeryturę nadal czynnie pracował, dojeżdżając do Międzylesia i do Warszawy, szkolił lekarzy, uczestniczył w posiedzeniach Oddziału Warszawskiego PTD.

Doktor Kazimierz Kalbarczyk odszedł tak szybko, jak żył. Kochał życie. Wciąż stawiał sobie kolejne wyzwania. Nigdy nie był szary, nijaki - zawsze nieprzeciętny. Niektórym sprawom nie poświęcał dużo czasu, innym oddawał się bez reszty. Do wyznaczonego celu dążył konsekwentnie, uparcie, nie zważając na jakiekolwiek trudności. Był niezwykle pracowity i sumienny, z pozoru szorstki i nieprzystępny, ale bardzo pogodny, dowcipny, pogwizdujący melodie, szczególnie te patriotyczne.

Kochał podróże, chciał zwiedzić wszystkie stolice Europy - udało się! Ostatnią stolicą w 1998 roku była Tirana. Potem zapragnął jechać dalej, był na wszystkich kontynentach z wyjątkiem Antarktydy, w 132 krajach świata, w niektórych kilkakrotnie (ryc. 1.). Tak więc wielokrotnie okrążył kulę ziemską! Marzył o podróży do odległych zakątków świata, chciał od-

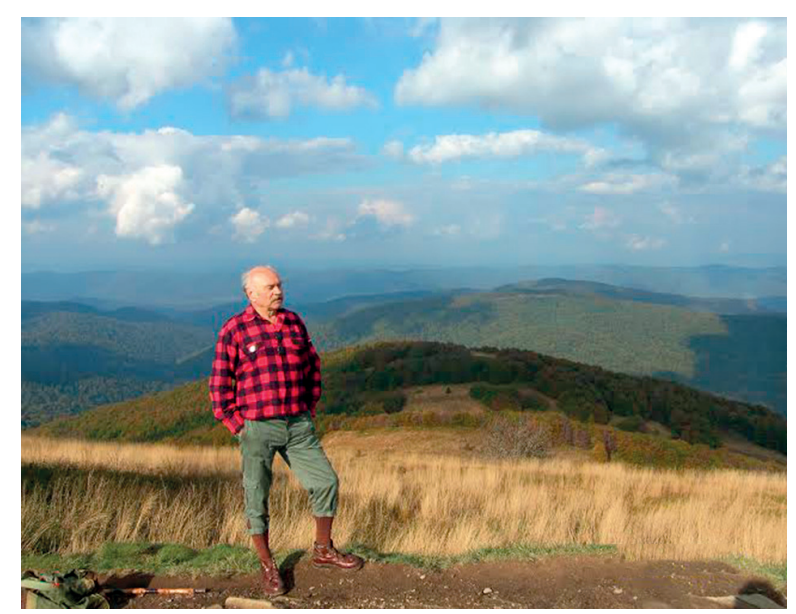

Rycina 2. Na bieszczadzkim szlaku 
wiedzić Gambię, Haiti, Mozambik, Koreę Północną, Afganistan... W Polsce szczególnie ukochał Bieszczady, był przewodnikiem górskim w tym regionie, znał każdy szlak, szczyt, połoninę (ryc. 2.). Zdobył złotą górską odznakę turystyczną. W ostatnich kilku latach rozkochał się w fotografowaniu ptaków. Podpatrywał przez lunetę ptasie zaloty, budowanie gniazd, wysiadywanie jaj i szkolenie młodych. Swoje fotografie krajobrazy, obiekty z listy Światowego Dziedzictwa Kultury i Przyrody UNESCO, zwierzęta, ptaki - prezentował na posiedzeniach Oddziału Warszawskiego PTD w 2007 i 2012 roku. Kolejną Jego pasją było gotowanie, szczególnie dań podpatrzonych w różnych krajach świata. Niektórzy mieli okazję spróbować!

Został odznaczony Srebrnym Krzyżem Zasługi i „Za wzorową pracę w służbie zdrowia”. W 2010 roku obchodził uroczyście na Akademii Medycznej w Białymstoku 50-lecie pracy zawodowej.

Był wielkim patriotą, zawsze uczestniczył w defiladzie 11 listopada w Dzień Niepodległości, podczas ostatniej w 2013 roku Prezydent Rzeczypospolitej Polskiej Bronisław Komorowski uścisnął mu dłoń był z tego bardzo dumny.
Ulubioną pieśnią „Pierwsza Brygada” pożegnaliśmy Doktora na Cmentarzu Parafialnym w Otwocku 25 listopada 2013 roku. Spoczął w grobie rodzinnym. Żegnała Go rodzina, liczne grono lekarzy i pacjentów.

Zapamiętamy Go jako Wielkiego Człowieka, oddanego lekarza, wytrwałego podróżnika, miłośnika ptaków i Wyjątkowego Przyjaciela. Pozostanie na zawsze w sercach lekarzy i chorych.

Pozostawił dwóch synów - Leszek jest lekarzem dermatologiem, Sławomir doktorem historii, pracownikiem naukowym Instytutu Pamięci Narodowej.

\section{Doktorze Kazimierzu!}

Stysząc śpiew ptaków, będziemy myśleć o Tobie! Na bieszczadzkim szlaku będziemy myśleć o Tobie! Patrzac przez mikroskop, będziemy myśleć o Tobie! Różnicując trudne przypadki, będziemy myśleć o Tobie! Stuchając pieśni "Pierwsza Brygada", będziemy myśleć o Tobie!

Magdalena Ciupińska 